\title{
Influence of non-edible oil on oviposition preference and hatchability of acarid mite, Tyrophagus putrescentiae Schrank on Groundnut
}

Rinkikumari Chauhan and Abhishek Shukla*

Department of Entomology, N.M. College of Agriculture, Navsari Agricultural University, Navsari (Gujarat) India

\section{ARITCLE INFO}

Received : 24.07 .2019

Revised : 09.09.2019

Accepted : 23.09 .2019

KEY WORDS :

Non-edible oils, Oviposition preference, Tyrophagus putrescentiae Schrank, Groundnut
*Corresponding author: Email : abhishekshukla@nau.in

\begin{abstract}
The effect of non-edible oils on oviposition and hatching of acarid mite Tyrophagus putrescentiae were studied during the year 2017-18 and 2018-19 at Acarology Laboratory, Department of Entomology, N.M. College of Agriculture, Navsari Agricultural University, Navsari, Gujarat. All the five non-edible oils evaluated have a significant effect on the fecundity of mite, T. putrescentiae. Fecundity was markedly reduced when groundnut seeds infested with mite were mixed with Neem, eucalyptus, castor, karanj and alsi oil at the different level of concentrations of non-edible oils i.e. 0.50,1.00 and $2.00 \mathrm{ml} / \mathrm{kg}$. The alsi oil was least effective in reducing egg laying of mite. The discrimination quotient (DQ) was maximum 0.59 in Neem oil at $2.00 \mathrm{ml} / \mathrm{kg}$ concentration and was minimum $(0.26)$ at $0.50 \mathrm{ml} / \mathrm{kg}$ in alsi oil treatment. Further, the per cent hatchability was maximum in the untreated groundnut seeds i.e. 96.67 per cent. In case of Neem oil at $2.00 \mathrm{ml} / \mathrm{kg}$ concentration only 64.50 per cent of eggs were hatched, while in case of alsi oil at $2.00 \mathrm{ml} / \mathrm{kg}$ concentration 89.33 per cent of eggs were hatched which were maximum as compared to all other non-edible oil treatments and less than that of untreated control.
\end{abstract}

How to view point the article : Chauhan, Rinkikumari and Shukla, Abhishek (2019). Influence of non-edible oil on oviposition preference and hatchability of acarid mite, Tyrophagus putrescentiae Schrank on Groundnut. Internat. J. Plant Protec., 12(2) : 152-159, DOI : 10.15740/HAS/IJPP/ 12.2/152-159, Copyright@ 2019: Hind Agri-Horticultural Society. 